\title{
Anxiety and Achievement in Statistics: A Systematic Review on Quantitative Studies
}

\author{
Farah Hani Abdul Ghani, Siti Mistima Maat \\ Center of Teaching and Learning Innovations, Faculty of Education, The National University of Malaysia, \\ Bangi, Selangor, Malaysia \\ Email: farahghani93@gmail.com,sitimistima@ukm.edu.my
}

How to cite this paper: Ghani, F. H. A., \& Maat, S. M. (2018). Anxiety and Achievement in Statistics: A Systematic Review on Quantitative Studies. Creative Education, 9, 2280-2290.

https://doi.org/10.4236/ce.2018.914168

Received: August 16, 2018

Accepted: October 27, 2018

Published: October 30, 2018

Copyright $(9) 2018$ by authors and Scientific Research Publishing Inc. This work is licensed under the Creative Commons Attribution International License (CC BY 4.0).

http://creativecommons.org/licenses/by/4.0/

Open Access

\begin{abstract}
Statistics is a challenging course for students and of which is often associated with subsequent concerns that may affect statistical achievement. Therefore, this study aims to identify the relationship between statistical concerns and statistical achievement in the systematic literature review context. This study also identifies the statistical method used in articles relating to the relationship between statistical concerns and statistical achievement. Four electronic databases were used; ERIC, DOAJ, Science Direct and Google Scholar. The eligibility of article selection is based on a few criteria that assess the relationship between anxiety and statistical achievement, quantitative research, access and use of Malay and English. 10 articles fulfilled the eligibility selection criteria. Extraction of data is based on the name of the researcher and the year, country, title, sample size, instrument, statistical component of statistical concerns, statistical methods and findings. The findings revealed that most of studies reported statistical concerns negatively affecting statistical achievements either directly or indirectly. Additionally, the findings also reported statistical methods frequently used in the study article were Structural Equation Modeling, correlations of 4 articles using this method followed by regression method, ANCOVA and MANCOVA. The results of this systematic literature survey provide insights of relationship between statistical concerns and statistical achievements. To conclude, educators should consider assessing the method of teaching that they use on students who are facing statistical concerns.
\end{abstract}

\section{Keywords}

Statistics, Anxiety, Achievement, Systematic, Literature Review

\section{Introduction}

Statistics is one of the important components in mathematics which focuses on 
methods of collecting, sorting, decomposing, analyzing numbered data and also drawing conclusions from the analysis of the data (Gani \& Amalia, 2015). Statistics is widely used and contributes significantly to various fields. However, statistical courses are well known amongst students as difficult courses (Sandoz, Butcher, \& Protti, 2017).

Most statistical courses are key requirements in the various programs offered by the university. Statistics can help students learn the skills needed to conduct their own research and interpret and critically evaluate the real-world concepts (Gal, 2002). However, statistical courses have also been found among courses that drive concern for graduate and non-mathematical students.

Statistical worries have been defined as any concerns that occur when dealing with statistics regardless of the type or complexity of statistical analysis conducted. (Onwuegbuzie, Daros, \& Ryan, 1997); (Chiu, 2013) propose a broader statistical definition of a negative state of emotional stimulation experienced by individuals as a result of dealing with statistics in any form and at any stage. This emotional state is preceded by a negative attitude towards statistics and which is related to it but different from mathematical concerns. In addition, Cruise and Wilkins (1980) have identified six components in statistical concerns: 1) statistical value, 2) interpretation concerns, 3) fears of exams and classes, 4) fear of asking for help, and 5) fear of statistical teacher (Macher, Paechter, Papousek, Ruggeri, Freudenthaler, \& Arendasy, 2013).

Students with high statistical concerns will be exposed to a variety of bad learning behaviors. They will spend some time and effort on learning, less efficient in organizing their learning environment, and less focusing on learning sessions (Onwuegbuzie, 2004). In addition, they are also more likely to postpone in completing assignments or supplies for the exam (Bell, 2001). Therefore, they have less knowledge about statistics and are less prepared to take the exam. This will cause students' academic achievement to be affected by statistical concerns.

Various studies have been conducted, which revealed a consistent negative relationship between statistical concerns and statistical achievements (Hanna \& Dempster, 2009; Onwuegbuzie, 1995; Tremblay, Gardner, \& Heipel, 2000). In other words, students with high statistical concerns are more likely to have lower achievement in statistical exams. For example, in a study conducted by (Galli, Ciancaleoni, Chiesi, \& Primi, 2008), a total of 162 (37\%) students failed in statistical courses at least once. The 162 students had statistical concerns higher than 280 students who passed the statistical course on the first attempt. In addition, (Chiesi \& Primi, 2010) used structural equation modeling to explore in 487 student samples on cognitive and non-cognitive factors that affect statistical achievement. They found that achievement was indirectly affected by statistical concerns through a negative attitude towards statistics.

While many studies have found negative relationships between statistical concerns and statistical achievements, it has been suggested that statistical con- 
cerns may have facilitating components (Onwuegbuzie \& Wilson, 2003). According to (Keeley, Zayac, \& Correia, 2008), the high level of statistical fears is in line with low performance, while statistical concerns at mid-level match to higher performance. It should be noted that concerns should not be removed as a whole to ensure students succeed because some concerns are acceptable (Keeley, Zayac, \& Correia, 2008). This is supported by (Macher, Papousek, Ruggeri, \& Paechter, 2015) that statistical concerns can also have a positive effect such as an increase in terms of effort as long as the level of concern is not too high.

The difference in the findings of studies related to statistical concerns can be attributed to various factors such as the quality of the study, the uncertainty of the definitive concerns, and the testing strategies used in the study. Therefore, this study will examine more closely the impact of statistical concerns on achievement. Exploring the study of statistical concerns relating to statistical achievement is one of the steps in understanding the needs of students in learning. In addition, studies on statistical concerns and achievements are less studied in the form of systematic surveys either locally or abroad. Hence, this systematic survey study aims to review articles relating to concerns and statistical achievements. In particular, the objectives of the study are as follows:

- To identify the statistical methods used in articles relating to the relationship between statistical concerns and statistical achievement.

- To identify the relationship between statistical concerns and statistical achievement.

\section{Methodology}

This study uses a systematic survey method. Systematic review is a way of identifying, evaluating critically and interpreting research findings related to research questions, research topics or the importance of such phenomena (Cooper, 2003). Hence, systematic survey research is best suited for studying articles on statistical concerns and statistical outcomes. The study involved 10 articles that examined the relationship between statistical concerns and statistical achievement. The qualitative analysis method was implemented in this study using content analysis. The handling and reporting of this study follows the guidelines outlined in Preferred Reporting Items for Systematic Reviews and Meta-Analyzes (PRISMA).

\subsection{Searching Strategy}

The article search is based on articles focusing on statistical concerns and statistical achievements published from January 2013 to November 2017. This search was conducted in four electronic databases namely the Education Resources Information Center (ERIC), Directory of Open Access Journals (DOAJ), Science Direct and Google Scholar. Searches in databases use the following search term combinations: statistical fears, statistical achievements, statistics anxiety, statis- 
tics achievement, and statistics performance. Researchers also handle search strategies on all the referral lists included in the article. Preliminary checks have been carried out based on the articles and abstracts. Full text is searched for articles that meet the eligibility criteria based on the title and abstract and then the final selection of studies is determined by the criteria included and excluded.

\subsection{Selection Criteria}

Selection of articles is based on systematic considerations on articles generated from article writing about statistical concerns and statistical achievement. Other sources of writing such as blogging, unpublished reports or proceedings are not included in this study. Scientific writing of these sources is not selected because of their objectivity and credibility which should be taken into account as they do not go through peer review process (Liyanagunawardena, Adams, \& Williams, 2013). The selected article is only quantitative and non-qualitative. In addition, selected articles only involve open-access articles. This is to simplify the procurement process and download the article. In addition, the study also selected articles written in Malay and English only. Articles will be excluded if only studying statistical concerns with regard to statistical achievement. In addition, this study only focuses on students at secondary and university level. Articles that use a sample size of less than 30 will also be excluded from the selection.

\section{Data Extraction}

The researcher reads his own articles based on the headings and abstracts to exclude articles that do not meet the criteria. Then, the researcher reads the full text in the remaining article to determine whether this article is to be included in the last study or not. Researchers use a coordinated data extraction form to record information on each study including researcher name and year, country, title, sample size, instrument, statistical component of statistical concerns, statistical methods and research findings. The instruments listed are only instruments related to testing statistical concerns and statistical achievement.

\subsection{Results and Discussions}

This systematic survey study aims to review articles relating to concerns and statistical achievements. Such a study can explore statistical concerns relating to statistical achievement and is one of the steps in understanding the needs of students towards learning. Figure 1 shows the flow of the article selection process article.

The initial search protocol identified 32,351 articles. Inspection by title and abstract eliminated 32,319 articles. The majority of articles were excluded because they do not assess the relationship between statistical concerns and 


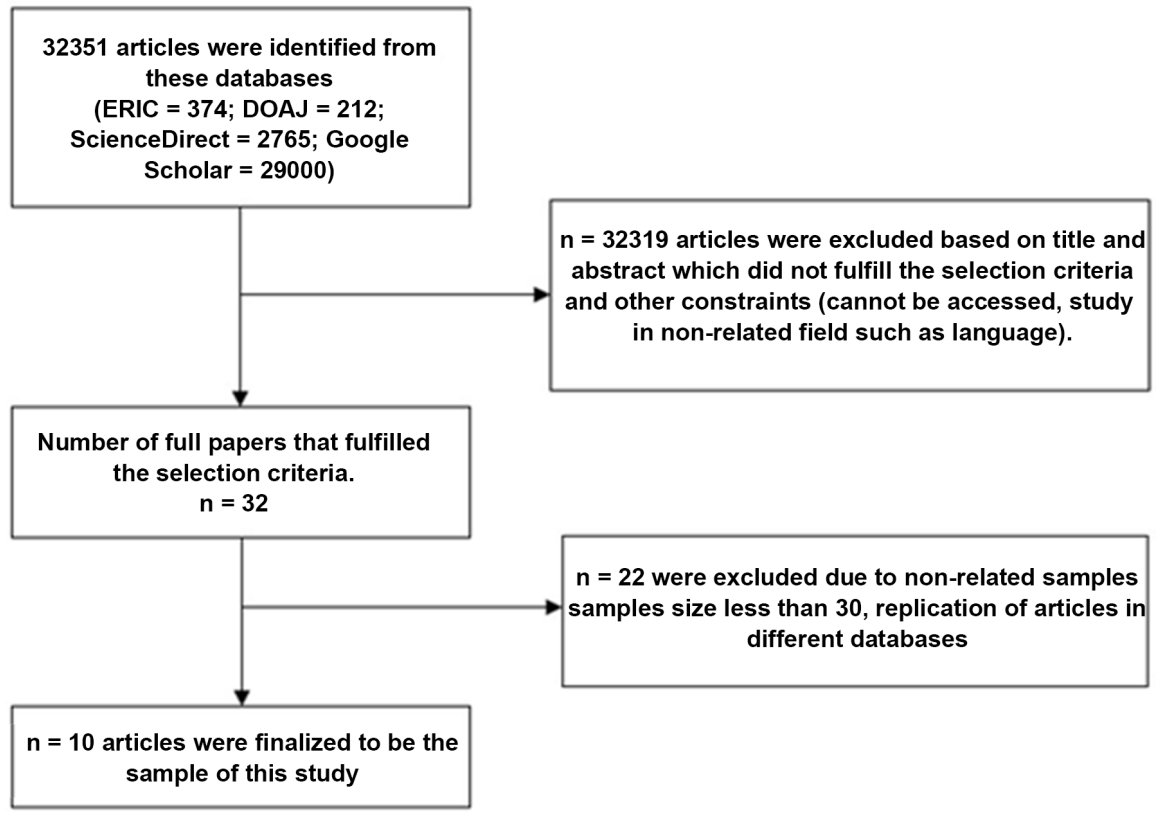

Figure 1. The flowchart of the article selection.

statistical achievements. Of the 32 full articles taken, 20 were further excluded and left a total of 12 articles meeting the criteria included and the criteria excluded in the study.

A summary of the articles featured included in this study is shown in Table 1. A total of 10 articles are identified to match the criteria included for this study. 3 articles are run in the United States, 2 in Austria, 2 in Spain, 1 in Malaysia, 1 in Turkey and 1 in Holland. The median for sample size of each study is 199 (range 97 - 947). In addition, there are several instruments used to test statistical concerns such as Statistical Anxiety Scale (SAS), Statistics Anxiety Rating Scale (STARS), Statistics Anxiety Measure (SAM) and Achievement Emotions Questionnaire (AEQ). Based on Table 1, the most commonly used instruments in the article were STARS instruments of 6 articles followed by 2 articles using SAS instruments, 1 articles using SAM instruments and 1 article using AEQ instruments.

For the components of statistical anxiety tested, there were 3 articles that tested all six components of statistical concerns expressed by Cruise and Wilkins (1980) in the study of Harris Shah Abd Hamid \& Muhamad Karimi Sulaiman (2014). Additionally, there are 4 articles that test the three components of the same statistical fears: anxiety on the exam and the statistical class, fear of asking for help and interpretation concerns. 1 article also tests three components but uses a different component of statistical fears that are concerns about exams and classes, statistical values and self-concept calculations. Additionally, there is 1 article testing two components of statistical concerns which are components of interpretation concerns and concerns over the examination and the statistical class. Whereas, there is 1 article that only tests component of statistical concerns that are components of anxiety and exams. 
Table 1. Summary of the selected articles.

\begin{tabular}{|c|c|c|c|c|c|c|c|}
\hline Researcher (s) & Country & Title & Sample size & Instrument & $\begin{array}{l}\text { Statistical } \\
\text { Anxiety } \\
\text { Components }\end{array}$ & $\begin{array}{l}\text { Methodology/ } \\
\text { Analysis }\end{array}$ & Findings \\
\hline $\begin{array}{l}\text { Sandoz, Butcher, } \\
\text { \& Protti (2017) }\end{array}$ & USA & $\begin{array}{l}\text { A Preliminary Examination } \\
\text { of Willingness and } \\
\text { Importance as Moderators } \\
\text { of the Relationship } \\
\text { Between Statistics Anxiety } \\
\text { and Performance }\end{array}$ & $\begin{array}{c}132 \\
\text { undergraduate } \\
\text { students }\end{array}$ & $\begin{array}{c}\text { Adaptation of } \\
\text { Statistical Anxiety } \\
\text { Scale (SAS), and } \\
\text { statistical quizzes }\end{array}$ & $\begin{array}{l}\text { - Examination } \\
\text { anxiety. } \\
\text { - Fear to get help } \\
\text { - Anxiety }\end{array}$ & $\begin{array}{l}\text { Multiple } \\
\text { regression }\end{array}$ & $\begin{array}{l}\text { The willingness and } \\
\text { importance of simplifying } \\
\text { the relationship between } \\
\text { statistics and performance } \\
\text { concerns in statistical } \\
\text { quizzes. }\end{array}$ \\
\hline $\begin{array}{l}\text { Paechter et al. } \\
\text { (2017) }\end{array}$ & Austria & $\begin{array}{l}\text { Mathematics Anxiety and } \\
\text { Statistics Anxiety. Shared } \\
\text { but Also Unshared } \\
\text { Components and } \\
\text { Antagonistic Contributions } \\
\text { to Performance in Statistics }\end{array}$ & $\begin{array}{c}225 \\
\text { undergraduate } \\
\text { students }\end{array}$ & $\begin{array}{l}\text { Statistics Anxiety } \\
\text { Rating Scale } \\
\text { (STARS) and } \\
\text { statistical exami- } \\
\text { nation }\end{array}$ & $\begin{array}{l}\text { - Examination and } \\
\text { class anxiety } \\
\text { - Fear to get help } \\
\text { - Fear of } \\
\text { Interpretation }\end{array}$ & $\begin{array}{c}\text { Structural } \\
\text { Equation } \\
\text { Modelling (SEM) }\end{array}$ & $\begin{array}{l}\text { Statistical worries have a } \\
\text { direct negative impact on } \\
\text { academic achievement }\end{array}$ \\
\hline $\begin{array}{l}\text { González et al. } \\
\quad(2015)\end{array}$ & Spain & $\begin{array}{c}\text { Anxiety in The Statistics } \\
\text { Class: Structural Relations } \\
\text { with Self-Concept, Intrinsic } \\
\text { Value, and Engagement in } \\
\text { Two Samples of } \\
\text { Undergraduates }\end{array}$ & $\begin{array}{c}947 \\
\text { undergraduate } \\
\text { students }\end{array}$ & $\begin{array}{l}\text { Emotions Ques- } \\
\text { tionnaire (AEQ) }\end{array}$ & $\begin{array}{l}\text { - Statistics class } \\
\text { anxiety }\end{array}$ & $\begin{array}{c}\text { Structural } \\
\text { Equation } \\
\text { Modelling (SEM) }\end{array}$ & $\begin{array}{l}\text { Students with higher } \\
\text { self-concept and intrinsic } \\
\text { value experience less } \\
\text { concern in statistical classes. } \\
\text { They have a higher } \\
\text { involvement which in turn } \\
\text { increases achievement }\end{array}$ \\
\hline $\begin{array}{l}\text { Eduljee \& } \\
\text { LeBourdais } \\
\quad(2015)\end{array}$ & USA & $\begin{array}{c}\text { Gender Differences in } \\
\text { Statistics Anxiety with } \\
\text { Undergraduate College } \\
\text { Students }\end{array}$ & $\begin{array}{c}156 \\
\text { undergraduate } \\
\text { students }\end{array}$ & $\begin{array}{l}\text { Statistical Anxiety } \\
\text { Rating Scale } \\
\text { (STARS) }\end{array}$ & $\begin{array}{l}\text { - Examination and } \\
\text { class anxiety } \\
\text { - Statistical value } \\
\text { - Self-efficacy }\end{array}$ & Correlations & $\begin{array}{l}\text { For male students, there is } \\
\text { no significant correlation } \\
\text { between statistical concerns } \\
\text { and course grades. As for } \\
\text { female students, there is a } \\
\text { significant correlation } \\
\text { between statistical concerns } \\
\text { and course grades }\end{array}$ \\
\hline Sesé et al. (2015) & Spain & $\begin{array}{c}\text { Can Attitudes Toward } \\
\text { Statistics and Statistics } \\
\text { Anxiety Explain Students' } \\
\text { Performance? }\end{array}$ & $\begin{array}{l}472 \text { undergra- } \\
\text { duate students }\end{array}$ & $\begin{array}{l}\text { Statistical Anxiety } \\
\text { Scale (SAS) and } \\
\text { statistics test }\end{array}$ & $\begin{array}{l}\text { - Examination and } \\
\text { class anxiety } \\
\text { - Fear to get help } \\
\text { - Anxiety }\end{array}$ & $\begin{array}{c}\text { Structural } \\
\text { Equation } \\
\text { Modelling (SEM) }\end{array}$ & $\begin{array}{l}\text { Statistical worries have } \\
\text { indirect negative effects on } \\
\text { achievement through } \\
\text { attitudes toward statistics }\end{array}$ \\
\hline $\begin{array}{l}\text { Harris Shah Abd } \\
\text { Hamid \& } \\
\text { Muhamad } \\
\text { Karimi Sulaiman } \\
\quad \text { (2014) }\end{array}$ & Malaysia & $\begin{array}{c}\text { Statistics Anxiety and } \\
\text { Achievement in a Statistics } \\
\text { Course among Psychology } \\
\text { Students }\end{array}$ & $\begin{array}{c}139 \\
\text { undergraduate } \\
\text { students }\end{array}$ & $\begin{array}{l}\text { Revised version of } \\
\text { Statistics Anxiety } \\
\text { Rating Scale } \\
\text { (STARS) and } \\
\text { mathematics quiz }\end{array}$ & $\begin{array}{l}\text { - Examination and } \\
\text { class anxiety } \\
\text { - Fear to get help } \\
\text { - Anxiety } \\
\text { - Statistical value } \\
\text { - Self-efficacy } \\
\text { - Fear of statistical } \\
\text { teacher }\end{array}$ & $\begin{array}{l}\text { Correlation and } \\
\text { Linear Regression }\end{array}$ & $\begin{array}{l}\text { There is no significant } \\
\text { relationship between } \\
\text { statistical concerns and } \\
\text { statistical achievement }\end{array}$ \\
\hline McKim (2014) & USA & $\begin{array}{c}\text { Understanding } \\
\text { Undergraduate Statistical } \\
\text { Anxiety }\end{array}$ & $\begin{array}{c}173 \\
\text { undergraduate } \\
\text { students }\end{array}$ & $\begin{array}{l}\text { Statistics Anxiety } \\
\text { Measure (SAM) }\end{array}$ & 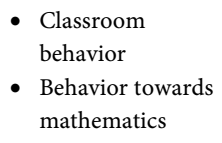 & Correlation & $\begin{array}{l}\text { There is a negative } \\
\text { relationship between } \\
\text { statistical concerns and } \\
\text { statistical achievement. }\end{array}$ \\
\hline $\begin{array}{l}\text { Ciftci, Karadag, } \\
\text { \& Akdal (2014) }\end{array}$ & Turkey & $\begin{array}{l}\text { Instruction of Statistics via } \\
\text { Computer-Based Tools: } \\
\text { Effects on Statistics' } \\
\text { Anxiety, Attitude and } \\
\text { Achievement }\end{array}$ & $\begin{array}{c}97 \\
\text { undergraduate } \\
\text { students }\end{array}$ & $\begin{array}{l}\text { Statistics Anxiety } \\
\text { Rating Scale } \\
\text { (STARS) and } \\
\text { Statistical } \\
\text { achievement scale }\end{array}$ & $\begin{array}{l}\text { - Examination and } \\
\text { class anxiety } \\
\text { - Fear to get help } \\
\text { - Anxiety } \\
\text { - Statistical value } \\
\text { - Self-efficacy } \\
\text { - Fear of statistical } \\
\text { teacher }\end{array}$ & $\begin{array}{l}\text { ANCOVA and } \\
\text { MANCOVA }\end{array}$ & $\begin{array}{l}\text { Computer-based statistics } \\
\text { teaching reduces statistical } \\
\text { concerns and increases } \\
\text { statistical performance. }\end{array}$ \\
\hline
\end{tabular}




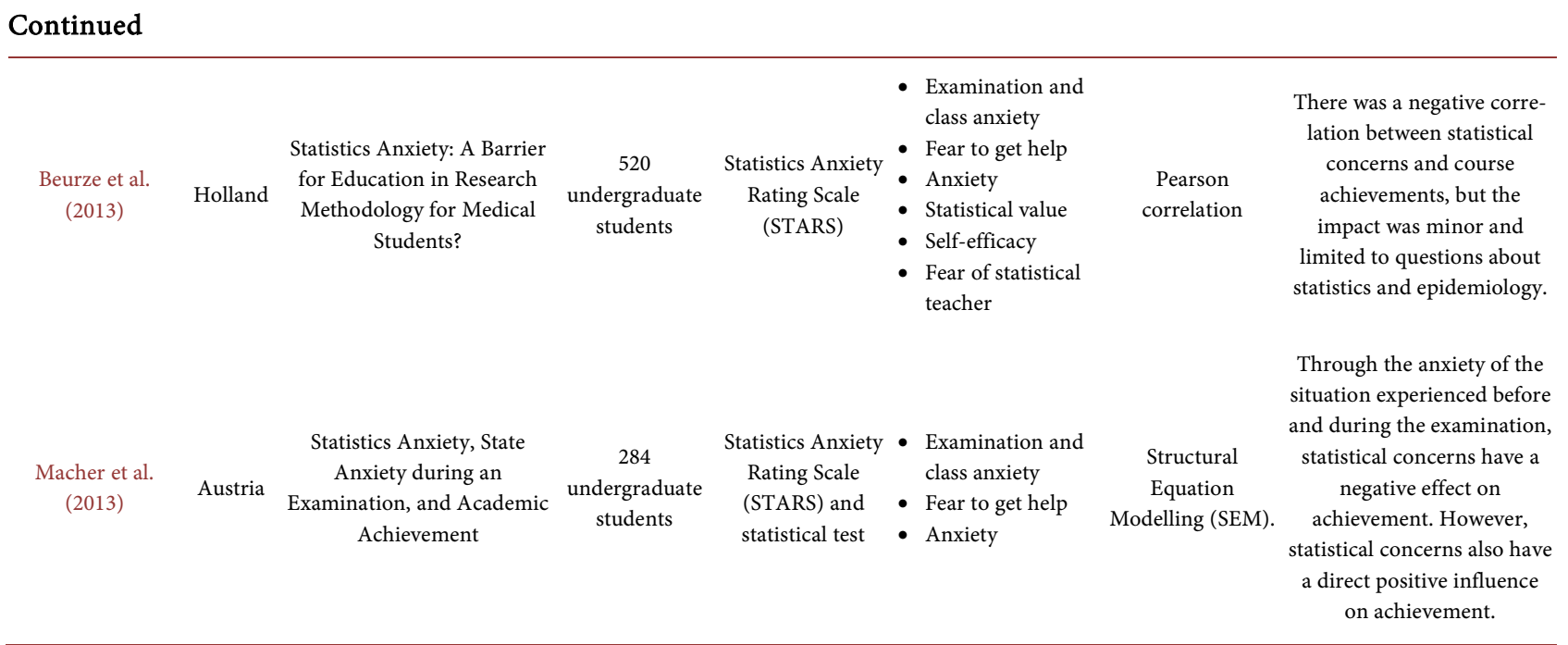

\subsection{Types of Data Analysis}

Based on the summary in Table 1, it is found that there are various methods of data analysis used in the review article to identify the relationship between statistical concerns and statistical achievement. The statistical method used frequently in the research article is structural equation modeling (SEM) and correlation that is 4 articles using this method. SEM is a multivariate statistical analysis that examines the relationship between constructs according to theory or previous studies through hypothesis model built (Hamid et al., 2013). This shows that the use of the SEM method is an appropriate method of studying the relationship model between the constructs of statistical and achievement concerns. The correlation is used to describe the strength of the relationship between the two variables, while the regression analysis focuses on the relationship between the variables (Zou, Tuncali, \& Silverman, 2003). Hence, using correlation and regression can provide contact information between statistical concerns and statistical achievement. There are 2 articles using regression analysis and 1 article using ANCOVA analysis as well as MANCOVA. Articles that carry out ANCOVA and MANCOVA analysis use quasi-experimental design designs and it helps to test causal relationships in situations where classic designs are difficult to be used or not (Neuman, 2008).

\subsection{Relationship between Statistical Anxiety and Achievement}

The findings of Table 1 summarize the relationship of statistical concerns and statistical achievements for each article. The results of the study findings, the majority of the articles reported statistical concerns negatively affect statistical achievement. 3 studies found statistical fears had a direct negative effect on statistical achievement (Beurze, Donders, Zielhuis, Vegt, \& Verbeek, 2013; McKim, 2014; Paechter, Macher, Martskvishvili, Wimmer, \& Papousek, 2017) While, two studies found that statistical concerns have a negative impact on achievement but not directly (Macher, Paechter, Papousek, \& Ruggeri, 2011; Sesé, Jiménez, 
Montaño, \& Palmer, 2015). This indirect negative effect is based on attitudes toward statistics and the concerns of the students before and during the examination. The concerns faced before the exam may be due to lack of preparation and this may affect the students' performance. This is supported by the statement of (Onwuegbuzie, 2004) which states that the concerns experienced before the examination are largely due to difficulties in time management and postponement during the preparation phase.

In addition, there are several elements that simplify the negative relationship between statistical concerns and statistical achievement. Among these elements are the willingness (individual openness to a particular personal experience), personal interests (Sandoz, Butcher, \& Protti, 2017), and high intrinsic concepts and intrinsic values (González, Rodríguez, Faílde, \& Carrera, 2015). Students with high self-concept and intrinsic value are more readily available in the classroom and are content to complete the assignment. This can reduce fears and thus increase achievement. This is supported by (Chiesi, Primi, \& Carmona, 2011) stating that good self-concept in high statistical and intrinsic value positively affects achievement and reduces statistical fears. Computer-based statistics teaching also reduces statistical concerns and increases statistical performance (Ciftci, Karadag, \& Akdal, 2014). This may be due to students understood better statistical functions and applications through computer-based learning than traditional learning and this understands statistical fears. The meta-analysis conducted by (Chiu, 2013) shows that computer-based learning has a positive impact on the success of the course, the development of positive attitude towards the course and facilitating student learning.

In addition, the analysis results also found that there was 1 article reporting no significant relationship between statistical concerns and statistical achievement (Harris Shah Abd Hamid \& Muhamad Karimi Sulaiman, 2014). This may be due to statistical concerns indirectly affecting statistical achievement. There is 1 article that compared statistical worrying relationships and gender-based statistical achievements. The results showed that for male students, there was no significant correlation between statistical concerns and course grades. While for female students, there is a significant correlation between statistical concerns and course grades (Eduljee \& LeBourdais, 2015). This is because the female students have higher statistical concerns from male students. According to Baharun and Porter (2009), male students have more confidence in the understanding of statistical topics and less concern in dealing with numbers than girls (Eduljee \& LeBourdais, 2015).

However, 1 article that report statistical concerns also have a direct positive influence on achievement (Macher, Papousek, Ruggeri, \& Paechter, 2015). This finding may be due to the goal of student motivation in a particular learning environment. Statistical worries may encourage motivation to avoid failure and negative consequences of failure (Pekrun \& Linnenbrink-Garcia, 2012 in González et al., 2016). 


\section{Conclusion}

The results of this systematic survey study provide an insight of the relationship between statistical concerns and statistical achievements as well as the elements associated with it. Based on statistical constructs, educators should consider re-evaluating the teaching methods that they use to students who are facing statistical related problems. Different teaching techniques such as computer-assisted teaching can reduce fears and thus improve statistical achievement. To emphasize statistical methods taught, it is recommended that students should engage with actual collected data. Among other ways in which teachers can influence students' feelings towards statistics, it is to discuss their concerns and give them a way to overcome their concerns.

This study focuses only on articles with quantitative studies only. The involvement of qualitative studies may reveal a clearer connection between constraints of concern to statistical achievement and support quantitative findings. Additionally, this study only covers articles in four electronic databases only. Further studies should include more electronic databases to add insights on statistical concerns and achievements. In addition, the involvement of qualitative studies also improves the current study.

\section{Conflicts of Interest}

The authors declare no conflicts of interest regarding the publication of this paper.

\section{References}

Bell, J. A. (2001). Length of Course and Levels of Statistics Anxiety. Education, 121, 713-716.

Beurze, S. M., Donders, A. R. T., Zielhuis, G. A., Vegt, F., \& Verbeek, A. L. M. (2013). Statistics Anxiety: A Barrier for Education in Research Methodology for Medical Students? Medical Science Educator, 23, 377-384.

https://doi.org/10.1007/BF03341649

Chiesi, F., \& Primi, C. (2010). Cognitive and Non-Cognitive Factors Related to Students' Statistics Achievement. Statistics Education Research Journal, 9, 6-26.

Chiesi, F., Primi, C., \& Carmona, J. (2011). Measuring Statistics Anxiety: Cross-Country Validity of the Statistical Anxiety Scale (SAS). Journal of Psychoeducational Assessment, 29, 559-569. https://doi.org/10.1177/0734282911404985

Chiu, Y. H. (2013). Computer-Assisted Second Language Vocabulary Instruction: A Meta-Analysis. British Journal of Educational Technology, 44, 52-56. https://doi.org/10.1111/j.1467-8535.2012.01342.x

Ciftci, S. K., Karadag, E., \& Akdal, P. (2014). Instruction of Statistics via Computer-Based Tools: Effects on Statistics Anxiety, Attitude and Achievement. Journal of Educational Computing Research, 50, 119-133. https://doi.org/10.2190/EC.50.1.f

Cooper, H. M. (2003). Editorial. Psychological Bulletin, 129, 3-9. https://doi.org/10.1037/0033-2909.129.1.3

Eduljee, N., \& LeBourdais, P. (2015). Gender Differences in Statistics Anxiety with Undergraduate College Students. The International Journal of Indian Psychology, 2, 69-82. 
Gal, I. (2002). Adults' Statistical Literacy: Meanings, Components, Responsibilities. International Statistical Review, 70, 1-51. https://doi.org/10.1111/j.1751-5823.2002.tb00336.x

Galli, S., Ciancaleoni, M., Chiesi, F., \& Primi, C. (2008). Who Failed Introductory Statistics? Mexico: International Congress on Mathematical Education.

Gani, I., \& Amalia, S. (2015). Alat Analisis Data: Aplikasi Statistik untuk Penelitian Bidang Ekonomi dan Sosial. Yogyakarta: Penerbit Andi.

González, A., Rodríguez, Y., Faílde, J. M., \& Carrera, M. V. (2015). Anxiety in the Statistics Class: Structural Relations with Self-Concept, Intrinsic Value, and Engagement in Two Samples of Undergraduates. Learning and Individual Differences, 45, 214-221. https://doi.org/10.1016/j.lindif.2015.12.019

Hanna, D., \& Dempster, M. (2009). The Effect of Statistics Anxiety on Students' Predicted and Actual Test Scores. The Irish Journal of Psychology, 30, 201-209. https://doi.org/10.1080/03033910.2009.10446310

Keeley, J., Zayac, R., \& Correia, C. (2008). Curvilinear Relationships between Statistics Anxiety and Performance among Undergraduate Students: Evidence for Optimal Anxiety. Statistics Education Research Journal, 7, 4-15.

Liyanagunawardena, T. R., Adams, A. A., \& Williams, S. A. (2013). MOOCs: A Systematic Study of the Published Literature 2008-2012. The International Review of Research in Open and Distributed Learning, 14, 202-227. https://doi.org/10.19173/irrodl.v14i3.1455

Macher, D., Paechter, M., Papousek, I., \& Ruggeri, K. (2011). Statistics Anxiety, Trait Anxiety, Learning Behaviour and Academic Performance. European Journal of Psychology of Education, 27, 483-498. https://doi.org/10.1007/s10212-011-0090-5

Macher, D., Paechter, M., Papousek, I., Ruggeri, K., Freudenthaler, H. H., \& Arendasy, M. (2013). Statistics Anxiety, State Anxiety during an Examination, and Academic Achievement. British Journal of Educational Psychology, 83, 535-549. https://doi.org/10.1111/j.2044-8279.2012.02081.x

Macher, D., Papousek, I., Ruggeri, K., \& Paechter, M. (2015). Statistics Anxiety and Performance: Blessings in Disguise. Frontiers in Psychology, 6, 1116. https://doi.org/10.3389/fpsyg.2015.01116

McKim, C. (2014). Understanding Undergraduate Statistical Anxiety. Journal of Research in Education, 24, 204-210.

Neuman, W. L. (2008). Social Research Methods: Qualitative and Quantitative Approaches. Istanbul: Yayinodasi.

Onwuegbuzie, A. J. (1995). Statistics Test Anxiety and Female Students. Psychology of Women Quarterly, 19, 413-418. https://doi.org/10.1111/j.1471-6402.1995.tb00083.x

Onwuegbuzie, A. J. (2004). Academic Procrastination and Statistics Anxiety. Assessment \& Evaluation in Higher Education, 29, 3-19. https://doi.org/10.1080/0260293042000160384

Onwuegbuzie, A. J., \& Wilson, V. A. (2003). Statistics Anxiety: Nature, Etiology, Antecedents, Effects, and Treatments: A Comprehensive Review of the Literature. Teaching in Higher Education, 8, 195-209. https://doi.org/10.1080/1356251032000052447

Onwuegbuzie, A. J., Daros, D. A., \& Ryan, J. (1997). The Components of Statistics Anxiety: A Phenomenological Study. Focus on Learning Problems in Mathematics, 19, 11-35.

Paechter, M., Macher, D., Martskvishvili, K., Wimmer, S., \& Papousek, I. (2017). Mathematics Anxiety and Statistics Anxiety. Shared but also Unshared Components and Antagonistic Contributions to Performance in Statistics. Frontiers in Psychology, 8, 1196. 
https://doi.org/10.3389/fpsyg.2017.01196

Sandoz, E. K., Butcher, G., \& Protti, T. A. (2017). A Preliminary Examination of Willingness and Importance as Moderators of the Relationship between Statistics Anxiety and Performance. Journal of Contextual Behavioral Science, 6, 47-52. https://doi.org/10.1016/j.jcbs.2017.02.002

Sesé, A., Jiménez, R., Montaño, J., \& Palmer, A. (2015). Can Attitudes toward Statistics and Statistics Anxiety Explain Students' Performance? Revista de Psicodidáctica 20, 285-304. https://doi.org/10.1387/RevPsicodidact.13080

Tremblay, P. F., Gardner, R. C., \& Heipel, G. G. (2000). A Model of the Relationships among Measures of Affect, Aptitude, and Performance in Introductory Statistics. Canadian Journal of Behavioral Science, 32, 40-48. https://doi.org/10.1037/h0087099

Zou, K. H., Tuncali, K., \& Silverman, S. G. (2003). Correlation and Simple Linear Regression. Radiology, 227, 617-622. https://doi.org/10.1148/radiol.2273011499 